\title{
Job Shift of The Indonesian International Return Migrant in Central Java Province
}

\author{
Suyanto* \\ Faculty of Cultural Science, Universitas Diponegoro, Semarang, Indonesia
}

\begin{abstract}
This study aims to explain: (i) shift jobs in Indonesian International Return Migrant (IIRM) between before and after becoming a international migrant; (ii) migrant jobs in the destination country and after returning to Indonesia; and (iii) duration of time as IIRM and number of countries of work. This study uses a theoretical framework of needs and stress theory. This study uses survey design and case studies and selected the location of studies in the Central Java. The determination of the sample size of this study uses the Krejcie and Morgan techniques. Based on the calculation results, the number of respondents in this study was 313 respondents. The number of informants for this study was 60 people. Data collection uses structured interview methods, in-depth interviews, and focus group discussions. Data analysis uses descriptive statistical analysis and qualitative descriptive analysis. The analysis showed that a significant shift in migrant worker occurred in the employment of labor who switched to trade, before working abroad as much as $22.7 \%$ to $9.3 \%$ and the trade sector from $4.8 \%$ to $20.4 \%$, in addition to the agricultural sector $(8.6 \%$ to $11.8 \%$ ) and services $(2.9 \%$ to $6.1 \%)$. The duration of time for migrants working abroad for more than 4 years is $50.8 \%$. The main objective of international migration for Indonesian migrants is Southeast Asia, 38\% and second, East Asia, which is almost $29 \%$. The employment sector that absorbs the most labor in various destination countries is domestic work $(69 \%)$, which includes $60 \%$ of domestic work (household work) and $8 \%$ in nursing homes. In addition, migrants work in the plantation sector, which is $6.5 \%$. These three jobs are known as smelly, heavy and dangerous (S.H.D) or in Indonesia as bau, berat, bahaya (3B), which are usually a relatively for work force segment of low education.
\end{abstract}

Key words: sift jobs; return migrant; abroad; Indonesia

${ }^{*}$ Corresponding author : suyanto@live.undip.ac.id 


\section{Introduction}

Indonesia is the second largest source of labor migration abroad after the Philippines. In the first quarter of 2012, more than 4 million Indonesian international migrants (IIM) worked abroad, especially in Southeast Asia and the Middle East [1]. In fact, in 2013 the Philippines was displaced by Indonesia in sending labor abroad with a total of 6.5 million people spread in 142 countries and originating from 392 districts / cities in Indonesia [2, 3]. This figure is only based on the data of workers who work abroad legally. In reality, IIMs who work illegally abroad, especially in the Southeast Asia region, are around one third of legal IIMs [4].

Previous studies also show that migrants return, especially international migrants such as "addicted" to always working abroad. This is more due to the use of remittance which tends to consumptive and investment needs [5, 6]. In addition, after becoming an international migrant they became a figure who splashed out with shopping and changed lifestyles than before working abroad so that within a few months back in Indonesia they had run out of money. In this condition, there is no other choice for them except to go abroad again. Such conditions occur almost repeatedly for the majority of return migrants $[7,8]$. This phenomenon occurs in areas of origin of migrant enclaves in Indonesia, such as East Nusa Tenggara, West Nusa Tenggara and Baweyan [9], Cilacap and Kendal [7, 10].

The main driving factors for migrants to return to work abroad are economic problems (very limited job opportunities and low income) in the country of origin (Indonesia) and broad employment opportunities and higher income levels in the destination country [9]. Even the findings of Haris [12] show that becoming IIM is a survival strategy for migrants and their families. However, several studies have shown that the ability of returning migrants cannot be fully utilized in productive economic behavior in the area of origin. This is caused by the limited employment opportunities in the area of origin and the mindset of returning migrants who do not yet have a plan for what to do after they no longer become IMs [13].

Return migration is the situation of migrants returning to their home country of their own choosing, after living abroad for a significant period of time [14]. The duration of international migrant work contracts is often based on the regulations of the destination country. Those who return to Indonesia within a certain period or permanently are known as returning migrants. Return migrants are defined as migrants returning to their home country of their own choosing and / or expiration of a residence permit or employment contract in the destination country [15].

At the macro level, migrants have experienced international re-increase in average human capital for sending countries [16]. In addition, by working abroad, international migrants can increase income and change the traditional mindset to modern. Thus, human capital savings migrants again provide economic benefits for him in the area of origin [14]. Migrants return with the quality of human capital carrying a number of capital, namely financial capital, social capital, human capital, leadership, and training [15].

Various studies conclude that the productive behavior of migrant economic returns in the area of origin is as a self-employed or a worker to others [17]. Migrants return to play 
an important role in encouraging development through new skills and savings obtained while working abroad [18]. Productive economic behavior is also supported by sociodemographic factors such as education, age and long time return and perceptions about work [19]. However, not always skills and work experience from abroad can be utilized in the area of origin [20].

This study uses a concluding theoretical framework of needs and stress that (i) a person experiences stress, both economically, socially, and psychologically at their place of origin (origin area). Each individual has different needs, so that an area is declared by someone as an area that can meet their needs, while others say no. (ii) There is a difference in the value of the territorial use between one place and another. If there is no difference in the value of one place to another, then there will be no mobility of the population [21].

Based on the background of the problem, the objectives of this study are (i) to explain the shift in IIRM work between before and after becoming a migrant; (ii) describes IIRM in the destination country of employment and employment after returning to Indonesia; and (iii) explain the duration of time as IIRM and the number of countries of work.

\section{Method}

This study uses survey design and case studies. Spatially, Central Java was chosen as the location of this study based on consideration that Central Java Province is a pockets of regional origin for international migrants nationally and migrants returning to Central Java have a high dependency by working abroad. The determination of the sample size of this study uses the Krejcie and Morgan techniques [22] (313 respondents). The number of respondents consisted of 69 men and 244 women. The number of speakers for in-depth interviews and FGDs is 60 people consisting of 33 IIRM and 30 stakeholders. The data collection uses structured interview methods (questionnaires), in-depth interviews, and focus group discussions. Data analysis used descriptive statistical analysis.

\section{Result and Discussion}

\section{Characteristics of Education Return Migrant}

The highest number of migrants returning in Central Java was graduated from Junior High School (JHC) at $42.8 \%$, followed by $30 \%$ of Primary School (PC) graduates, while Senior High School (SHC) graduates were $22.4 \%$, and did not complete Primary School as much as $4.2 \%$. However, it turns out that there were two respondents $(0.6 \%)$ who graduated from college (Figure 1). This shows that migrants returning to Central Java are still dominated by JHC graduates. Even though the unemployment rate in all sectors of the Indonesian economy is high, the most low-skilled workforce is going abroad. 


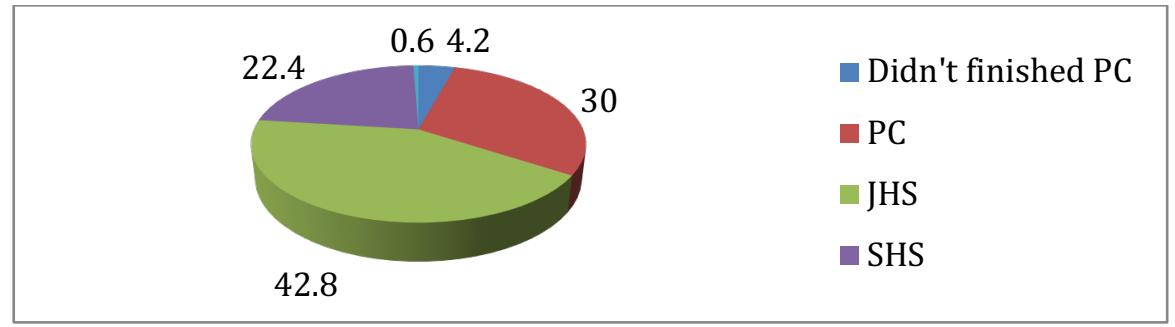

Fig. 1. Respondents by Education

Source: Primary Data 2018.

\section{Job Sift of Indonesian International Return Migrant}

In general, before and after working abroad the IIRMs do not work, ie $43.1 \%$ each and almost $45 \%$. In fact, when IMs return to Indonesia, there is an increase in the number of unemployed people because they choose to be housewives, while household income is the responsibility of their husbands. second place is working as laborers, 70 people $(22.4 \%)$, and the smallest number is one fisherman $(0.3 \%)$. This fact proves that the limited employment in Indonesia and the low quality of human resources caused them to look for work abroad. The desire to improve the standard of living by working abroad overcomes the picture of violence, exploitation, and deportation. In fact, this is sometimes done even if you have to go illegally.

A significant shift in employment is in the employment of workers who before working abroad nearly $23 \%$ fell to nine percent after working from abroad. The shift from their work which was originally a laborer is turned into farmers and fishermen, which was originally $8.6 \%$, to $11.8 \%$ and traders, which were from $4.8 \%$ to $20.8 \%$ and services which were from around three percent to six percent (Figure 2 ). This shows that the actual economic remittances that they get are used for productive businesses, in addition to consumptive and economic. This result also corrects the results of previous studies, such as the study of Suyanto and Muzakka ${ }^{7}$ which explains that migrant income is generally returned to meet consumption and investment needs. In addition, this finding also sharpens the findings of Tani and Mahateau ${ }^{17}$ who explain that the productive behavior of migrant economic returns in the area of origin is either as a self-employed or a worker to others because these findings explain more explicitly about the work they do.

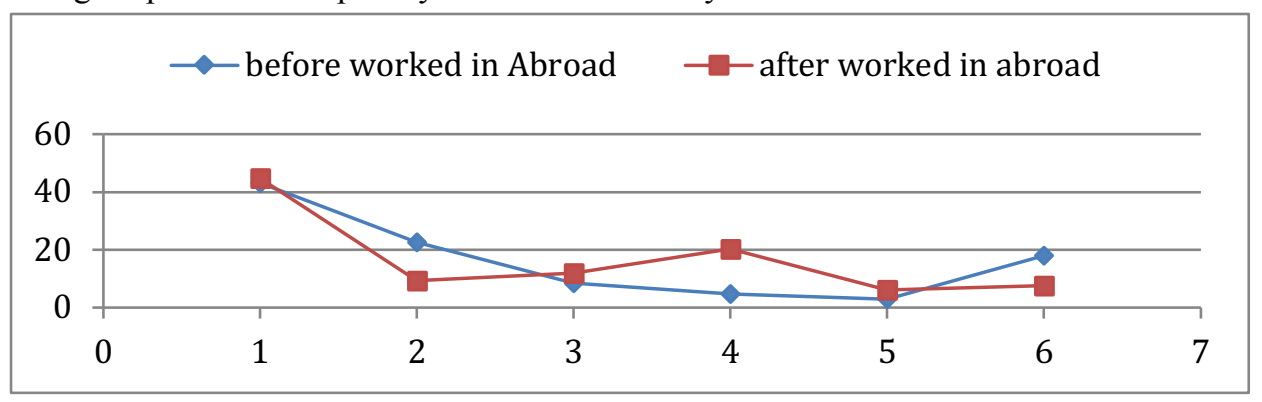

Fig. 2. Respondents' Work Before and After Working in Abroad Source: Primary Data 2018. 
The main objective of international migration of Indonesian migrants is Southeast Asia, which is 119 people (38\%). Meanwhile, the second place which is the destination of international migration is East Asia, such as Japan, Korea, Taiwan and Hong Kong, which is almost $29 \%$. Those who have worked in Southeast Asia and the Middle East were one person $(0.3 \%)$ and worked in East Asia and the Middle East as much as one percent (Table 1). The reason for the high interest in IIRM choosing to work in the Southeast Asian region is because salaries are higher than in Middle Eastern countries and facilities and protection for IIRM is better or more noticed by recipient countries.

Table 1. Destination Countries International Migration

\begin{tabular}{|l|r|r|}
\hline \multicolumn{1}{|c|}{ Region / Destination Countries } & Amount & Percentage \\
\hline Southeast Asia & 119 & 38 \\
\hline East Asia (Japan, Korean, Taiwan, Hong Kong) & 90 & 28.8 \\
\hline The Middle East & 30 & 9.6 \\
\hline Southeast Asia and East Asia & 15 & 4.8 \\
\hline Southeast Asia and The Middle East & 1 & 0.3 \\
\hline East Asia and The Middle East & 3 & 1 \\
\hline Others & 55 & 17.6 \\
\hline Total & 313 & 100 \\
\hline
\end{tabular}

Source: Primary Data 2018.

The employment sector that absorbs the most labor in various destination countries is domestic work which absorbs $60 \%$ of Indonesia's international migrants. Around eight percent of Indonesian migrant workers work in the care of elderly people who are nothing but domestic work, so the total number of Indonesian migrant workers working in the domestic sector is almost $69 \%$. This is reasonable because $78 \%$ of Indonesian migrant workers are women and in terms of education, $77 \%$ have no elementary or junior high school education. The population with low education in general is absorbed in the $3 \mathrm{~B}$ (bau, berat, bahaya (Indonesian)) occupational sector which is smelly, heavy and dangerous (S.H.D) [23]. Migrant workers with junior high school education or lower than working in the domestic sector are agriculture, especially plantations which reach almost $6.5 \%$ (see Table 2). Jobs in the plantation sector are generally in Malaysia, women are generally in vegetable gardens and men in rubber, palm oil, and processing of forest products, especially timber. Meanwhile, migrant workers absorbed in the industrial sector (factories) are those with a high school education or equivalent, generally they work in East Asia, such as South Korea, Hong Kong and Taiwan. 
Table 2. Overseas Work Sector

\begin{tabular}{|c|l|c|c|}
\hline No & Overseas Work Sector & Amount & Percentage \\
\hline 1 & Household & 189 & 60.4 \\
\hline 2 & Hospital & 1 & 0.3 \\
\hline 3 & Elderly Home & 26 & 8.3 \\
\hline 4 & Farm & 20 & 6.4 \\
\hline 5 & Industry/Factory & 45 & 14.4 \\
\hline 6 & Others & 32 & 10.2 \\
\hline & & 313 & 100 \\
\hline
\end{tabular}

Source: Data Primary 2018.

Generally Indonesian migrant workers work abroad more than 4 years, which is almost $52 \%$ and almost $30 \%$ work abroad more than six years. Less than $20 \%$ of migrant workers who work abroad is only a maximum of 2 years, and almost $31 \%$ work abroad within a span of 3-4 years (Table 3). These data reinforce the findings of Suyanto's study ${ }^{5}$ that Indonesian migrants have a high dependency to work abroad. This is in line with the need and stress theory which concludes that the tendency of migrants to migrate to an area that has a greater benefit value than the region (Country) of origin. This is quite clear because working abroad in addition to getting a much higher wage than in Indonesia is also job opportunities in the destination countries more broadly.

Table 3. Length of Working in Abroad

\begin{tabular}{|l|c|c|}
\hline \multicolumn{1}{|c|}{ Length of Working } & Jumlah & Persen \\
\hline <=2 years & 58 & 18.5 \\
\hline 3-4 years & 96 & 30.7 \\
\hline 5-6 years & 66 & 21.1 \\
\hline > 6 years & 93 & 29.7 \\
\hline Total & 313 & 100 \\
\hline
\end{tabular}

Source: Primary Data 2018.

Although more than half Indonesian migrants work abroad more than 4 years, but the majority only work in one country (almost 62\%). It shows that on the one hand when it feels comfortable working at the same employer or person is suitable it tends to return to the same employer or the same job. In addition, among those who have worked abroad for a long time due to work in several countries. This is in line with Robert E. Norris's migration theory [21] that between the origin (country) region and the destination (country) region there are intervening opportunities. Region (country) as the first target of job seekers from the area of origin to the main destination area. The movement is a leaping frog in increasing effort (step-wise movers). 
Table 4. Number of Countries of Work

\begin{tabular}{|c|l|c|c|}
\hline No. & Number of Countries of Work & Amount of & Percentage \\
\hline 1 & One Country & 193 & 61.7 \\
\hline 2 & Two Countries & 75 & 24.0 \\
\hline 3 & Three Countries & 19 & 6.1 \\
\hline 4 & Four Countries & 2 & 0.6 \\
\hline 5 & Not Answering & 24 & 7.7 \\
\hline & Total & 313 & 100.0 \\
\hline
\end{tabular}

Source: Primary Data 2018.

\section{Conclusion}

Based on the above data analysis, it can be summarized several things. The narrowness of employment in Indonesia and the low quality of human resources cause high rates of international migration. The desire to improve the standard of living by working abroad overcomes the picture of violence, exploitation and deportation. The main goals of international migration for Indonesian migrants are Southeast Asia at 38\% and East Asia at almost $29 \%$.

The significant shift in employment between before international migration and after returning to Indonesia was labor, trade, services and agriculture. Workers' employment from almost $23 \%$ dropped to nine percent; farmers and fishermen, which were originally $8.6 \%$, to 11.8 ; traders who were originally $4.8 \%$ to 20.8 ; and services, which were originally around three percent to six percent. This shows that the actual economic remittances that they get are used for productive businesses, in addition to consumptive and economic.

The occupation sector that absorbs the most labor in various destination countries is domestic work $(69 \%)$, which covers $60 \%$ of domestic work and $8 \%$ in nursing homes. In addition, migrants work in the plantation sector, which is $6.5 \%$. These three jobs are known as $3 \mathrm{~B}$ jobs in Indonesian or SHD, which are smelly, heavy and dangerous, which are usually a relatively low segment of education work force.

\section{ACKNOWLEDGEMENT}

This research funded by Directorate of Research and Community Services, Ministry of Research, Technology, and Higher Education that funding this research (2018-2019), Number of Contract: 10186/UN7.P4.3/PP/2018 \& 2019. Thank to field assistants: Elsa Fitrianita, Syaeful Anwar, Suryo Wicaksono and 6 other students who conducted data collection. 


\section{References}

1. Doi, Yoko. Bagaimana Membantu TKI Menciptakan Kesejahteraan. LIONMAG. The Inflight Magazine of Lion Air. Edisi November. Hal. 36-38 (2012).

2. Nurhayat, Wiji. "Jumlah TKI Capai 6,5 Juta, Tersebar di 142 Negara" dalam detikfinance.com, diunduh 14 Maret 2013,17:40 (2013).

3. Suara Pembaruan, 27-12 (2013).

4. Kompas, 19 July (2013).

5. Suyanto. "Pemanfaatan Modal Manusia dan Modal Sosial Migran Kembali di Daerah Asal di Kabupaten Kendal Jawa Tengah”. Laporan Penelitian UP3 FIB Undip (2015).

6. Haris, Abdul dan Nyoman Adika. Dinamika Kependudukan dan Pembangunan di Indonesia: Dari Perspektif Makro ke Realitas Mikro. Yogyakarta: LESF I (2002).

7. Suyanto dan Muzakka,M. " Peran dan Kemandirian Tenaga Kerja Wanita dalam Rumah Tangga: Studi Kasus Tenaga Kerja Wanita Desa Penanggulan Kecamatan Pegandon Kab.Kendal”. Laporan Penelitian Kajian Wanita Lemlit Undip (2002).

8. Muzakka, Muh dan Suyanto. "Mobilitas Internasional Tenaga Kerja Wanita: Studi Perubahan Sosial Ekonomi Rumah Tangga Tani Desa Banjarsari Kecamatan Nusawungu, Kendal”. Laporan Penelitian Kajian Wanita, Lembaga Peneltian Universitas Diponegoro (2003)

9. Mantra, IB. Migrasi Sirkuler di Indonesia. Yogyakarta: PSKK UGM (1995).

10. Suyanto. Pemanfaatan Remitan Ekonomi dan Ketergantungan Migran Kembali Bekerja di Luar Negeri. Endogami, Vol. 2 No. 1, Desember (2018).

11. BPS. Jawa Tengah dalam Angka 2018. Semarang: BPS Jawa Tengah((2019)

12. Haris, Abdul dan Nyoman Adika. Dinamika Kependudukan dan Pembangunan di Indonesia: Dari Perspektif Makro ke Realitas Mikro. Yogyakarta: LESF I (2002)

13. Pitoyo, Joko Agus. "Bina Keluarga Migran Menuju Sejahtera: Pemanfaatan Remitan Produktif". Dalam Tukiran, AJ Pitoyo, dan PM Kutannegara (Eds), Akses Penduduk Miskin terhadap Kebutuhan Dasar. Yogyakarta:PPSK UGM (2010).

14. Dustmann, Christian, and Yoram Weiss. Return Migration: Theory and Empirical Evidence. CreAM Discussion Paper Series CPD No. 02/07. Departement of Economics and CreAM (Center for Research and Analisys of Migration), University College London (2007).

15. Trisnaningsih. "Pemanfaatan Modal Manusia dan Modal Sosial Mantan Tenaga Kerja Indonesia di Provinsi Lampung". Disertasi untuk meraih derajat Doktor Ilmu Kependudukan Universitas Gadjah Mada ((2013).

16. Mayr, Karin and Giovani Peri. "Return Migration as A Chanel of Brain Gain". Working Paper 14039. National Bureau of Economic Research. Massachusetts Avenue. Cambridge,M.A (2010).

17. Tani, Massimiliano and Sthepane Mahuteau. Return Migration and Working Chices. European University Institute. San Domenico Di Fiosole (2008). 
18. McCormick, Barry and Jackline Wahba. "Return International Migration and Geographic Inequality: The Case of Egypt". Department of Economic , University of Southamption, UK (2002).

19. Setiadi. “Masalah Reintegrasi Sosial dan Ekonomi Migran”. Populasi, Vol. 12, No.1 (2001).

20. Pitoyo, Joko Agus dan Kasto. "Pemagangan Luar Negeri Tenaga Kerja: Proses, Pendapatan, dan Alih Teknologi”. Populasi. Vol. 17,No.1 (2006).

21. Mantra, IB. Demografi Umum. Yogyakarta: Pustaka Pelajar (2015).

22. Mantra, Ida Bagoes. Langkah- Langkah Penelitian Survai Usulan Penelitian dan Laporan Penelitian. Yogyakarta : Badan Penerbit Fakultas Geografi UGM (2000).

23. Singarimbun,M. Penduduk dan Perubahan. Yogyakarta: Pustaka Pelajar ((1997). 